\title{
EFEKTIVITAS KONSELING KELOMPOK TRAIT AND FACTOR UNTUK MENINGKATKAN KEMATANGAN KARIR SISWA KELAS X SMA NEGERI 4 BAUBAU
}

\author{
Rosmawati T. 1), Suriani 2) \\ 1) Prodi Bimbingan Konseling, Universitas Muhammadiyah Buton \\ 2) Mahasiswa Prodi Bimbingan Konseling, Universitas Muhammadiyah Buton \\ Email: rosmawatitaherong123@gmail.com
}

\begin{abstract}
Abstrak
Penelitian ini merupakan penelitiaan kuantitatif dengan metode experimen. desain penelitian yang digunakan dalam penelitian ini adalah Pre-Experimental design bentuk one group pretest-postest design. Hasil penelitian menunjukan hasil Layanan konseling kelompok trait and factor efektif untuk meningkatkan kematangan karir siswa kelas X SMA Negeri 4 Baubau tahun ajaran 2017-2018 hal tersebut dapat menunjukan bahwa kematangan karir siswa dapat ditingkatkan melalui konseling kelompok trait and factor. Selain itu untuk mengetahui apakah efektivitas konseling kelompok trait and factor dapat meningkatkan kematangan karir siswa, benar-benar dapat ditingkatkan melalui konseling kelompok trait and factor dengan menggunakan bantuan prongram SPSS for windows 17.0 menujukan bahwa nilai $\mathrm{P}=0,002$ maka dapat disimpulkan bahwa konseling kelompok trait and factor efektiv dapat meningkatkan kematngan karir siswa.
\end{abstract}

Kata kunci: Konseling Kelompok Trait And Factor, Kematangan Karir

\begin{abstract}
This research is a quantitative research with experimental methods. The research design used in this study was a PreExperimental design in the form of one group pretest-posttest design. The results showed the results of the effective trait and factor counseling service group to improve the career maturity of class X students of SMA 4 Baubau in the 2017-2018 school year. This could indicate that students' career maturity could be improved through counseling on the trait and factor group. In addition, to find out whether the effectiveness of the trait and factor counseling group can improve the career maturity of students, it can actually be improved through the counseling of trait and factor groups using SPSS prongram for windows 17.0 to show that the P value is 0.002. effective factors can improve student career abilities.
\end{abstract}

Keywords: And Factor Trait Group Counseling, Career Maturity 


\section{SANG PENCERAH}

Volume 4, Nomor 2, Agustus 2018, Hlm. 57-63

Rosmawati T. dan Suriani: Efektivitas Konseling Kelompok ...

\section{Pendahuluan}

Kematangan karir sebagai proses mengacu kepada bagai mana individu menentukan, membuat pilihan atau keputusan dan bagai mana individu mengkombinasikan antara kondisi dirinya dengan lingkungan. Sedangkan kematangan karir sebagai hasil mengacu kepada apa yang telah dicapai individu, apakah dia mantap atau tidak dengan pilihan atau keputusan yang telah dipilihnya.

Siswa Kelas X SMA Negeri 4 Baubau tidak terlepas dari persoalan kematangan karir tersebut yakni belum terlalu memahami bakat dan minat yang dimilikinya sehingga siswa tidak dapat mengetahui arah atau tujuan karir yang akan dikerjakanyan. Berdasarkan hasil wawancara dengan siswa SMAmengenai kematagan karirnya tentang melanjutkan atau memilih jurusan MIA/IIS atau IBD, apakah Siswa SMA berani dalam mengambil keputusan karirnya dan kemampuan untuk menetapkan prioritasnya. Berdasarkan masalah yang terkait diatas maka akan menggunakan Trait And Factor untuk meningkatkan kematangan karir siswa kelas $X$ SMA Negeri 4 Baubau. Menurut pandangan Parson dan williamson (Winkel, 2004) ciri khas dari teori Trait And Factor ialah bahwa seseoran dapat menemukan vocasional yang cocok baginya dengan mengkorelasikan kemampuan, potensi, dan wujut minat yang dimilikinya dengan kualitas-kualitas yang secara objektif dituntut bila akan memegang vokasional tertentu.

Adapun hasil penelitian terdahulu yang diteliti oleh Bayu Afiko Denta tahun (2016) yang berjudul Penerapan Konseling Kelompok Model Trait And Factor untuk meningkatkan Kemantapan Pilihan Karir Siswa Kelas XI SMK Negeri 10 Surabaya, dengan peningkatan rata-rata pre-test 189,75 dan rata-rata post-test 236, selisih 46,25. dapat disimpulkan bahwa konseling kelompok model trait and factor dapat meningkatkan kemantapan pilihan karir pada siswa SMK Negeri 10 Surabaya. Berdasarkan uraian di atas, fokus penelitian ini adalah bagaimanakah Efektivitas Konseling Kelompok melalui Trait And Factor untuk Meningkatkan Kematangan Karir Siswa Kelas X SMA Negeri 4 Baubau?

Penelitian ini bertujuan untuk mengetahui Efektivitas Konseling Kelompok melalui Trait And Factor untuk Meningkatkan Kematangan Karir Siswa Kelas X SMA Negeri 4 Baubau.

\section{Metode Penelitian}

\section{Pendekatan Penelitian}

Penelitian ini merupakan penelitiaan kuantitatif dengan metode experimen merupakan metode percobaan untuk mempelajari pengaruh dari variabel tertentu terhadap variabel yang lain, melalui uji coba dalam kondisi khusus yang sengaja diciptakan, (Fathoni, 2006: 99)

\section{Desain Penelitian}

Adapun desain penelitian yang digunakan dalam penelitian ini adalah PreExperimental design bentuk one group pretestpostest design. Paradigma penulisannya dapat digambarkan sebagai berikut:

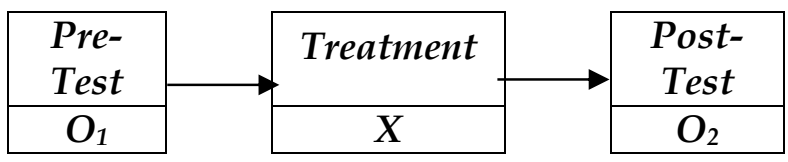

\section{Gambar 1 Desain Penelitian Eksperimen}

Keterangan gamabar:

$\begin{array}{llll}\mathrm{O}_{1} & = & \text { Pre-Test (kondisi sebelum } \\ \text { dilakukan treatment) } & \\ \mathrm{X}= & \text { Treatment } \\ \mathrm{O}_{2}= & \begin{array}{l}\text { Post-Test (kondisi } \\ \text { diberikan treatment) }\end{array}\end{array}$




\section{SANG PENCERAH}

Volume 4, Nomor 2, Agustus 2018, Hlm. 57-63

Rosmawati T. dan Suriani: Efektivitas Konseling Kelompok ...

\section{Lokasi dan Waktu Penelitian}

Lokasi pelaksanaan penelitiaan ini telah dilaksanakan di kelas X SMA Negeri 4 Baubau di Jalan Betoambari, No 73 Kelurahan Tanganapada Murhum Kota

\section{Populasi dan Sampel Penelitian}

Populasi dalam penelitian ini adalah siswa kelas $X$ pada semester ganap tahun ajaran 2017/2018 yang berjumlah 120 siswa adapaun penelitian ini akan di selenggarakan di SMA Negeri 4 Baubau. Penarikan sampel menggunakan teknik Proporsional Random Sampling. Jadi sampel penelitian yang di ambil dari jumlah populasi sebesar $(10 \% \times 120)$ adalah 12 Siswa Kelas X SMA Negeri 4 Baubau tahun ajaran 2017/2018.

\section{Teknik Pengumpulan Data}

Instrumen penelitan menggunakan skala sikap. Adapun blue print skala sikap pengukuran tersebut seperti berikut ini:

Tabel 1 Skala Pengukuran Sikap Kematangan Karir

\begin{tabular}{ccccc}
\hline Pernyataan & SS & S & TS & STS \\
\hline Favorable & 4 & 3 & 2 & 1 \\
Unfovorable & 1 & 2 & 3 & 4
\end{tabular}

Sumber hasil penelitian, 2018

\section{Pembahasan}

Gambaran Umum Kematangan Karir Siswa Kelas X SMA Negeri 4 Baubau Tahun Ajaran 2017/2018

Gambaran umum kematangan karir siswa kelas X SMA Negeri 4 Baubau Tahun Ajaran 2017/2018 ini, diperoleh dengan mengolah data hasil dari jawaban siswa pada lembar isian instrumen kematangan karir yang di kelompokan kedalam tiga kategori, yaitu tinggi, sedang, dan rendah.
Tabel 2 Gambaran Umum Kematangan Karir Siswa Kelas X SMA Negeri 4 Baubau Tahun Ajaran 2017/2018

\begin{tabular}{cccc} 
Rentang & Frekuensi & Kategori & Persentase (\%) \\
\hline 161 & 2 & Tinggi & 17 \\
$\leq 117-161$ & 8 & Sedang & 66 \\
& 2 & Rendah & 17 \\
\hline Jumlah & $\mathbf{1 2}$ & & $\mathbf{1 0 0}$
\end{tabular}

Berdasarkan tabil di atas terdapat kategori tinggi sebanyak 2 responden $(17 \%)$, kategori sedang sebanyak $8 \quad(66 \%)$. Sedangkan kategori rendah sebanyak 2 responden $(17 \%)$, yang artinya bahwa pada kategori ini menunjukan bahwa kematangan karir siswa masih kurang.

Untuk lebih jelasnya di lihat pada grafik 4.1 di bawah ini :

17\% Kematangan Karir

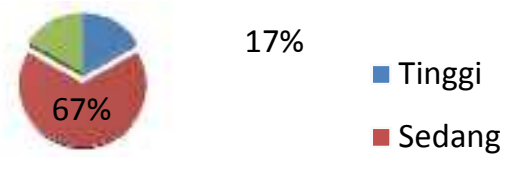

Grafik 1 Gambaran Umum Kematangan Karir Siswa Kelas X SMA Negeri 4 Baubau

Efektivitas Konseling Kelompok Trait And Factor Untuk Meningkatkan Kematangan Karir Siswa Kelas X SMA Negeri 4 Baubau

Sesuai dengan tujuan penelitian, yaitu meningkatkan kematagan karir Siswa Kelas $X$ SMA Negeri 4 Baubau, berikut akan diuraikan terlebih dahulu tingkat kematangan karir siswa yang menjadi sampel penelitian dari total keseluruhan hasil pre-test Kelas X SMA Negeri 4 Baubau maka diambil sampel sebayak 10 orang siswa dengan kriteria 8 orang siswa dalam kategori rendah dan 2 orang siswa dalam 


\section{SANG PENCERAH}

Volume 4, Nomor 2, Agustus 2018, Hlm. 57-63

Rosmawati T. dan Suriani: Efektivitas Konseling Kelompok ...

kategori sedang dengan menggunakan teknik purposive random sampling untuk selanjutnya diberikan treatment berupa konseling kelompok Trait And Factor. Adapun dilihat pada tabel 4.3 berikut ini.

Tabel 3 Hasil Pre-test kematangan karir Siswa Kelas X SMA Negeri 4 Baubau Tahun Ajaran 2017/2018

\begin{tabular}{cccc}
\hline Rentang & Frekuensi & Kategori & Persentase (\%) \\
\hline$\leq 161$ & 2 & Tinggi & 17 \\
$117-161$ & 8 & Sedang & 66 \\
$\geq 117$ & 2 & Rendah & 17 \\
\hline Jumlah & $\mathbf{1 0}$ & & $\mathbf{1 0 0}$ \\
\hline
\end{tabular}

Dari tabel diatas dapat dilihat bahwa ada 10 siswa yang akan mendapatkan treatment diantaranya $8(66 \%)$ siswa dengan kategori sedang dan 2 (17\%) siswa dengan kategori rendah yang diambil dari pengambilan sampel secara acak. Pemilihan sampel ini memiliki tingkat kematangan karir yang berbeda-beda seperti pengetahuan diri, pengambilan keputusan, informasi karir, integrasi pengetahuan tentang diri dan karir, dan perencanaan karir. Sedangkan diberikan perlakuan yaitu dengan memberikan konseling kelompok trait and factor selama 5 kali pertemuan kepada 10 siswa yang diambil menjadi sampel pnelitian yang sebelumnya dengan hasil pre-test 8 dari kategori sedang dan 2 dalam kategori rendah. Setelah diberikan perlakuan kemudian dilaksanakan post-test untuk mengetahu peningkatan kematangan karir siswa Kelas X SMA Negeri 4 Baubau. Hasil yang diperoleh dari post-test disajikan dalam bentuk tabel 4 sebagai berikut:

Tabel 4 Hasil Post-tes kematangan karir Siswa Kelas X SMA Negeri 4 Baubau Tahun Ajaran 2017/2018

\begin{tabular}{cccc}
\hline Rentang & Frekuensi & Kategori & Persentase (\%) \\
\hline$\geq 154$ & 8 & Tinggi & 80 \\
$137-154$ & 1 & Sedang & 10 \\
$\leq 137$ & 1 & Rendah & 10 \\
\hline Jumlah & $\mathbf{1 0}$ & & $\mathbf{1 0 0}$ \\
\hline
\end{tabular}

Hal tersebut menggambarkan mayoritas siswa kelas X SMA Negeri 4 Baubau meningkat $70 \%$ sangat tinggi dari segi aspek kematangan karir kematangan karir seperti pengetahuan diri, minat pekerjaan, mengambil keputusan, menerima informasi mengenai karir, nilai dan aturan kehidupan. Untuk lebih jelasnya di lihat pada grafik 4.7 di bawah ini :

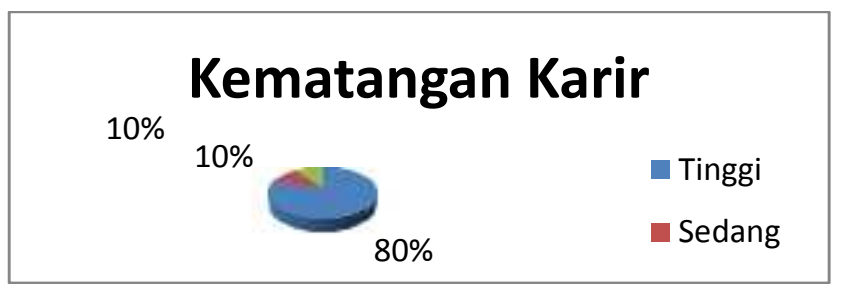

\begin{tabular}{clrr} 
Grafik 2 & \multicolumn{1}{c}{ Hasil Pos-Tes } & Tingkat \\
& Kematangan Karir & Siswa \\
& Kelas X SMA Negeri 4 \\
& Baubau tahuan ajaran \\
& $2017 / 2018$
\end{tabular}

Berdasarkan uraian diatas maka dapat disimpulkan bahwa kematangan karir siswa kelas X SMA Negeri 4 Baubau dapat meningkat setelah diberikan layanan konseling kelompok trait and factor selama 5 (lima) kali sesuai degan materi yang akan dibahas terkait masalah siswa.

\section{Perbandingan Hasil Perhitungan Pre- tes dan Post-test}

Adapun perbedaan kematangan karir siswa sebelim dan sesudah diberikan layanan konseling kelompok trait and factor pada 10 siswa kelas X SMA Negeri 4 Baubau lebih jelasnya akan dilihat pada tabel 4.5 Berikut: 


\section{SANG PENCERAH}

Volume 4, Nomor 2, Agustus 2018, Hlm. 57-63

Rosmawati T. dan Suriani: Efektivitas Konseling Kelompok ...

Tabel 5 Perbandingan Hasil Pre-Test Dan Post-Test Tingkat Kematangan Karir Siswa kelas X SMA Negeri 4 Baubau tahun ajaran 2017/2018

\begin{tabular}{|c|c|c|c|c|c|c|c|c|}
\hline \multirow[b]{2}{*}{$\begin{array}{c}\text { Respo } \\
\text { nden }\end{array}$} & \multicolumn{3}{|c|}{ Pre-test } & \multicolumn{3}{|c|}{ Post-test } & \multicolumn{2}{|c|}{ Peningkatan } \\
\hline & $\sum$ & $\%$ & $\mathbf{K}$ & $\sum$ & $\%$ & $\mathbf{K}$ & $\begin{array}{c}\text { Seli } \\
\text { sih }\end{array}$ & $\%$ \\
\hline R1 & 140 & 5.83 & S & 160 & 6.66 & $\mathrm{~T}$ & 20 & 0.83 \\
\hline R2 & 129 & 5.37 & $S$ & 159 & 6.62 & $\mathrm{~T}$ & 30 & 1.25 \\
\hline R3 & 143 & 5.95 & $S$ & 162 & 6.72 & $\mathrm{~T}$ & 19 & 0.38 \\
\hline $\mathrm{R} 4$ & 119 & 4.95 & S & 145 & 6.04 & S & 26 & 1.09 \\
\hline R5 & 132 & 5.5 & $\mathrm{~S}$ & 165 & 6.87 & $\mathrm{~T}$ & 33 & 1.37 \\
\hline R6 & 119 & 4.95 & $S$ & 120 & 5 & $\mathrm{R}$ & 79 & 0.05 \\
\hline R7 & 120 & 5 & $\mathrm{~S}$ & 155 & 6.45 & $\mathrm{~T}$ & 35 & 1.45 \\
\hline R8 & 115 & 4.79 & S & 161 & 6.68 & $\mathrm{~T}$ & 45 & 3.62 \\
\hline R9 & 109 & 4.54 & $\mathrm{R}$ & 170 & 7.08 & $\mathrm{~T}$ & 61 & 3.45 \\
\hline R10 & 108 & 4.5 & $\mathrm{R}$ & 159 & 6.62 & $\mathrm{~T}$ & 51 & 2.12 \\
\hline $\begin{array}{l}\text { Rata- } \\
\text { Rata } \\
\mathrm{N}=10\end{array}$ & \multicolumn{3}{|c|}{$1234: 10=123.4$} & \multicolumn{3}{|c|}{$1515: 10=151.5$} & & \\
\hline
\end{tabular}

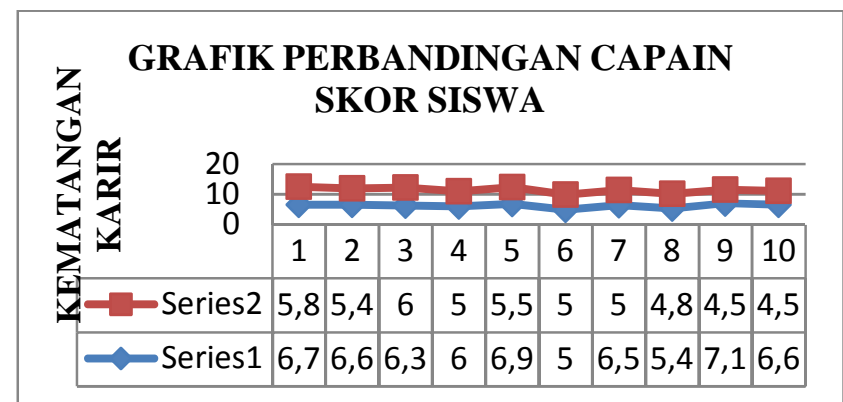

Grafik 3 Perbandingan Kematangan Karir Siswa Kelas $X$ SMA Negeri 4 Baubau

Berdasarkan hasil penelitian meningkatkan kematangan karir siswa kelas X SMA Negeri 4 Baubau melalui konseling kelompok dengan trait and factor, didapat hasil bahwa kematangan karir siswa dapat ditingkatkan melalui konseling kelompok trait and factor. Konseling kelompok ini dilaksanakan sebanyak 5 sesi. Pelaksanaan konseling kelompok diikuti oleh 10 anggota kelompok dan peneliti sebagai pemimpin kelompok.

Jadi dari total keseluruhan hasil pretest kelas X SMA Negeri4 Baubau maka diambil sampel sebanyak 10 siswa dengan 8 $(80 \%)$ kategori rendah dan $2(20 \%)$ kategori sedang dengan menggunakan teknik purposive random sampling untuk selanjutnya diberikan treatment berupa layanan konseling kelompok trait and factor. Kemudian diperoleh hasil pos-test 7 (70\%) siswa dengan kategori tinggi, $1(10 \%)$ siswa dengan kategori sedang dan 2 (20\%) siswa dengan kategori rendah.

Dillard (dalam Syamsiah, 2012:13) menyatakan bahwa kematangan karir merupakan sikap individu dalam membuat keputusan karir yang ditampakan oleh tingkat konsistensi pilihan karir dalam suatu periode tertentu.

Setelah peneliti melakukan konseling kelompok, peneliti mengadakan post-test kepada anggota yang mengikuti konseling kelompok dengan trait and factor. Adapun persentase rata-rata tingkat kematangan karir dari hasil post-test tersebut sebesar $77.83 \%$ meningkat dari sebelumnya pada saat pre-test sebesar $65.79 \%$. Jumlah tersebut mengalami persentase peningkatan rata-rata sebesar $12.04 \%$.

Sedangkan Pencapaian pada aspek pengetahuan tentang diri pada post-test memperoleh presentase $18.61 \%$ menggambarkan adanya selisi $5.04 \%$ dari hasil pre-test sebesar $13.57 \%$, yang berada pada kategori tinggi. Hal tersebut mendakan bahwa secara umum siswa telah memiliki perubahan pengetahuan tentang diri yang baik.

Pencapaian pada aspek pengambilan keputusan pada pos-tes memperoleh presentase $10.63 \%$ menggambarkan adanya selisi $2.18 \%$ dari hasil pre-test sebesar $8.45 \%$ yang berada pada kategori tinggi. Hal tersebut menandakan bahwa secara umum siswa telah memiliki perubahan pengambilan keputusan yang baik. Pencapaian pada aspek informasi karir pada pos-tes memperoleh presentase $19.35 \%$ menggambarkan adanya selisi $2.95 \%$ dari hasil pre-test sebesar $16.4 \%$ yang berada pada kategori tinggi. Hal tersebut menandakan bahwa secara umum siswa telah memiliki informasi karir yang baik. Pencapaian pada aspek intengrasi pengetahuan tentang diri 


\section{SANG PENCERAH}

Volume 4, Nomor 2, Agustus 2018, Hlm. 57-63

\section{Rosmawati T. dan Suriani: Efektivitas Konseling Kelompok ...}

dan karir pada pos-tes memperoleh presentase $10.03 \%$ menggambarkan adanya selisi $1.09 \%$ dari hasil pre-test sebesar $11.12 \%$ yang berada pada kategori tinggi. Hal tersebut menandakan bahwa secara umum siswa telah memiliki intengrasi pengetahuan tentang diri dan karir yang baik.

Pencapaian pada aspek perencanaan karir pada pos-tes memperoleh presentase 23.65\% menggambarkan adanya selisi 9.13\% dari hasil pre-test sebesar $14.52 \%$ yang berada pada kategori tinggi. Hal tersebut menandakan bahwa secara umum siswa telah memiliki perencanaan karir yang baik. Berdasarkan data hasil penelitian secara kseluruhan terjadi peningkatan skor kematangan karir sebesar 78\%. Yang mana skor per aspek sebelum mengikuti konseling kelompok trait and factor sebesar $66 \%$ dan skor kematangan karir siswa setelah megikuti konseling kelompok trait and factor sebesar 12\%. Williamson dalam (Didi Tarsidi: 2007) merupakan seorang pendukung kuat konseling berdasarkan teori trait and factor. Penggunaan prosedur konseling Williamson menggunakan pendekatan trait and factor yang dikembangkan dari karya Parsons. Bahkan ketika diintegrasikan ke dalam teori-teori bimbingan karir lain, pendekatan trait and faktor memainkan peranan yang sangat vital. Dampak dan pengaruhnya terhadap perkembangan teknik-teknik asesmen dan penggunaan informasi tentang karir sangat besar.

\section{Simpulan}

Simpulan penelitian ini bahwa menunjukan hasil Layanan konseling kelompok trait and factor efektif untuk meningkatkan kematangan karir siswa kelas X SMA Negeri 4 Baubau tahun ajaran 20172018 hal tersebut dapat menunjukan bahwa kematangan karir siswa dapat ditingkatkan melalui konseling kelompok trait and factor. Selain itu untuk mengetahui apakah efektivitas konseling kelompok trait and factor dapat meningkatkan kematangan karir siswa, benar-benar dapat ditingkatkan melalui konseling kelompok trait and factor dengan menggunakan bantuan prongram SPSS for windows 17.0 menujukan bahwa nilai $\mathrm{P}=0,002$ maka dapat disimpulkan bahwa konseling kelompok trait and factor efektiv dapat meningkatkan kematngan karir siswa.

\section{Daftar Pustaka}

Alvarez, G.M. 2008. Career Maturity: A Prioriy for secondary education. Journal of Research in Educational Psychology. Vol 6(3) No 16

Abdurrahmat, Fathoni. 2006. Metodologi Penelitian \& Teknik Penyusunan Sakripsi. Jakarta: PT Rineka Cipta.

Arikunto, Suharsini. 2006. Penelitian Tindakan Kelas. Jakarta: Bina Aksara.

Fenti, Hikmawati. 2010. Bimbingan Konseling. Jakarta: Rajawali Press.

Gonzalez, M. A. 2008. Career Maturity: A Priority For Secondary Education. Electronical Journal of Research in Educational Psychology. ISSN: 1696-1095. Nomor 16, Volume 6 (3),749-772

Greenhaus, J. H, dan Callanan, G. A. 2006. Enclycopedia of career development. Vo.2 Unites States of America : Sage Publications, Inc.

Herawati, Yetti. 2010. Program Bimbingan dan Konseling untuk Mengembangkan Kematangan Karir Siswa. Jurnal Penelitian. Bandung: PPB FIP UPI Bandung 


\section{SANG PENCERAH}

Volume 4, Nomor 2, Agustus 2018, Hlm. 57-63

Rosmawati T. dan Suriani: Efektivitas Konseling Kelompok ...

Komandyahrini, E \& Hawadi. 2008. Hubungan self - Efficacy $\mathcal{E}$ dan kematangan dalam memilih karir siswa Program Percepatan Belajar (penelitian pada SMA Negeri 4 Bau-bau)

Lathifah, Nuryanto I. 2010. Profil Kematangan Karir Siswa SMK. Skripsi. Bandung: PPB FIP UPI Bandung

Latipun. 2008 Psikologi Konseling. Malang: UMM Press

Manrehu, M,T. 1998. Pengantar Bimbingan dan Konselig karir. Jakarta: Departemen Pendidikan \& Kebudayaan

Mugiarso, Heru. 2007. Bimbingan dan Konseling. Semarang: UPT UNES Press.

Prayitno dan Amti, Erman.2008. Dasar-Dasar Bimbingan dan Konseling. Jakarta: Rineka Cipta

Ridwan. 2011. Belajar Mudah Penelitian Untuk Guru, Karyawan Dan Peneliti Muda. Bandung: Alfabeta.

Salami, S.O. 2008. Gender, identity status and career maturity of adolescents in the South Nigeria. Journal of Social Sciences, 16, 35-49

Sharf, Richard S. 2006. Applying career Development Theory to Counseling. Canada: Thomson Books/ Cole

Smedley, et, al. (2003). Differences in Career Mautrity among Adjudicated and NonadjudicatednMale Student with and without Disabilities. Journal of Employment Counceling.

Sugiyono. 2008. Statistik Untuk Penelitian. Bandung: CV Alfabeta.
2012. Metide Penelitian Kuantitatif dan RED. Bandung: Alfabeta.

Super, D. E. 1980. A Life-span, Life-space Approach to career Development. Journal of Vocational Behavior 16, hal 282-298.

Supriatna. 2009. Layanan Bimbingan Karir di Sekolah Menengah. Bandung: Depdiknas dan UPI.

Susanti, E. 2008. Hubungan Self-Efficacy dengan Kematangan Karir. Tesis Jurusan Bimbingan dan Konseling SPS UPI Bandung: tidak diterbitkan 